\title{
Soil Carbon Sequestration by Switchgrass and No-Till Maize Grown for Bioenergy
}

\author{
Ronald F. Follett • Kenneth P. Vogel • Gary E. Varvel • \\ Robert B. Mitchell • John Kimble
}

Published online: 4 May 2012

(C) The Author(s) 2012. This article is published with open access at Springerlink.com

\begin{abstract}
Net benefits of bioenergy crops, including maize and perennial grasses such as switchgrass, are a function of several factors including the soil organic carbon (SOC) sequestered by these crops. Life cycle assessments (LCA) for bioenergy crops have been conducted using models in which SOC information is usually from the top 30 to $40 \mathrm{~cm}$. Information on the effects of crop management practices on SOC has been limited so LCA models have largely not included any management practice effects. In the first 9 years of a long-term $\mathrm{C}$ sequestration study in eastern Nebraska, USA, switchgrass and maize with best management practices had average annual increases in SOC per hectare that exceed $2 \mathrm{Mg} \mathrm{Cyear}^{-1}$ (7.3 $\mathrm{Mg} \mathrm{CO}_{2}$ year $^{-1}$ ) for the 0 to 150
\end{abstract}

Electronic supplementary material The online version of this article (doi:10.1007/s12155-012-9198-y) contains supplementary material, which is available to authorized users.

\section{R. F. Follett}

Soil-Plant-Nutrient Research Unit, USDA-ARS, NRRC,

Bldg. D, Ste. 100, 2150 Centre Ave.,

Fort Collins, CO 80526, USA

K. P. Vogel $(\bowtie) \cdot$ R. B. Mitchell

Grain, Forage, and Bioenergy Research Unit, USDA-ARS,

137 Keim Hall, University of Nebraska,

Lincoln, NE 68683-0937, USA

e-mail: Ken.Vogel@ars.usda.gov

G. E. Varvel

Agroecosystems Management Research Unit, USDA-ARS,

118 Keim Hall, University of Nebraska,

Lincoln, NE 68583-0937, USA

J. Kimble

USDA-NRCS National Soils Laboratory (retired),

151 East Hill Church Road,

Addison, NY 14801, USA soil depth. For both switchgrass and maize, over $50 \%$ of the increase in SOC was below the $30 \mathrm{~cm}$ depth. SOC sequestration by switchgrass was twofold to fourfold greater than that used in models to date which also assumed no SOC sequestration by maize. The results indicate that $\mathrm{N}$ fertilizer rates and harvest management regimes can affect the magnitude of SOC sequestration. The use of uniform soil C effects for bioenergy crops from sampling depths of 30 to $40 \mathrm{~cm}$ across agro-ecoregions for large scale LCA is questionable.

Keywords Switchgrass $\cdot$ Maize, soil carbon $\cdot$ Soil organic carbon · Bioenergy $\cdot$ Sustainability $\cdot$ Carbon sequestration

\section{Introduction}

Soil organic carbon (SOC) and its sequestration has a major impact on the long-term environmental sustainability of bioenergy crop production systems because of its effect on soil fertility and function and its impact on greenhouse gas fluxes [1]. Models such as GREET [2,3], DAYCENT [4], and CQESTR [5] are used to evaluate the potential environmental benefits or liabilities of bioenergy crops and are based on published data with soil sampling depths of 30 to $40 \mathrm{~cm}$. Life cycle assessments (LCAs) completed to date [6-12] have used these or similar models and their assumptions which to date have given little consideration to the effects of production management practices on SOC.

Perennial grasses such as switchgrass (Panicum virgatum L.) are known to sequester SOC [13-17], but the long-term effects of management practices such as $\mathrm{N}$ fertilization rate and harvest management on SOC sequestration by switchgrass are unknown. Perennial grasses could be used as bioenergy crops on about 20 million ha $\left(\mathrm{ha}=10,000 \mathrm{~m}^{2}\right)$ of 
marginal or idle cropland in the USA alone [18]. Approximately $40 \%$ of USA maize (Zea mays L.) grain production is used for fuel ethanol production and the non-grain biomass or stover remaining after grain harvest has been proposed as a significant cellulosic feedstock for advance biofuels production $[18,19]$. No-till or minimum-till farming practices have increased in the USA because of their conservation benefits and reduced production costs [20]. Information on the effect of maize stover removal under no-till management on soil $\mathrm{C}$ from long-term studies has not been available to date [21]. Most of the research on SOC in agricultural production systems focused on $\mathrm{C}$ in the 0 to $30 \mathrm{~cm}$ depth [22-27]. A few studies in which soil sampling has been conducted at greater depths indicate that production agriculture affects soil $\mathrm{C}$ deeper in the soil profile $[28,29]$.

We initiated a replicated, long-term, non-irrigated soil C sequestration study in 1998 in eastern Nebraska, USA, to evaluate the effects of $\mathrm{N}$ fertilizer and harvest management treatments on SOC for switchgrass managed for biomass production and for a no-till maize production system with and without stover removal. It is the longest on-going $\mathrm{C}$ sequestration study on these crops grown for bioenergy. Our hypotheses were that $\mathrm{N}$ fertilization and harvest management practices affect soil $\mathrm{C}$ sequestration in both no-till maize and switchgrass biomass production systems and that these changes occur deeper than $30 \mathrm{~cm}$ in the soil profile. Herein, we report the changes in SOC that occurred during the period from 1998 to 2007.

\section{Materials and Methods}

\section{Experiment Field}

The field used in the study was similar to the marginally productive fields expected to be used for switchgrass biomass production and is in the western part of the main maize production area of the USA. It is located on the University of Nebraska's Agricultural Research and Development Center (ARDC), Ithaca, Nebraska, USA (latitude 41.151, longitude 96.401 which is $50 \mathrm{~km}$ west of Omaha, NE. The field has Yutan silty clay loam (fine-silty, mixed, superactive, mesic Mollic Hapludalf) and Tomek silt loam (fine, smectitic, mesic Pachic Argiudoll) soils. The ranges in the surface three depths of the Yutan soil for water $\mathrm{pH}$ and for CEC were 6.2 to 6.8 and 26 to $32 \mathrm{cmoles} \mathrm{kg}^{-1}$, respectively. The corresponding range in the surface three depths of the Tomek soil were water $\mathrm{pH}$ values of 6.1 to 7.0 and a CEC range of from 24.4 to $32.3 \mathrm{cmoles} \mathrm{kg}^{-1}$. It is one of the least productive fields of the ARDC and is typical of marginally productive cropland fields that might be used for switchgrass production for bioenergy. The field used in the study was previously in sorghum
(Sorghum bicolor (L.) Moench) in 1996 and in soybeans (Glycine max (L.) Merr.) in 1997.

\section{Experimental Design}

The study is a randomized $(r=3)$ complete block split-split plot experimental design. Large plots were used so that field scale equipment could be used. Main plot lengths are the width of the field $(150 \mathrm{~m})$ and are $18 \mathrm{~m}$ wide. Main plot treatments were two cultivars of switchgrass, Trailblazer and Cave-in-Rock, and no-till maize. The maize hybrid used was a commercial glyphosate (Roundup ${ }^{\circledR}$ ) tolerant hybrid adapted to the region. The experiment was established in 1998 with the planting of the switchgrass plots. In 1998, plots designated for the no-till maize treatments were planted to glyphosate tolerant soybeans and grown using no-till management. No-till maize production began in 1999 .

Main plots were subdivided into three subplots which were used for $\mathrm{N}$ fertility treatments. Subplots are $30 \mathrm{~m}$ long $\times 18 \mathrm{~m}$ wide and are separated by $15 \mathrm{~m}$ wide alleys . Nitrogen $(\mathrm{N})$ fertilizer rates were randomly assigned to the subplots within species main plots. No fertilizer was applied during the establishment year for the switchgrass. In 1999, $\mathrm{N}$ fertilizer treatments were $\mathrm{N} 1=0, \mathrm{~N} 2=80, \mathrm{~N} 3=180$, and $\mathrm{N} 4=240 \mathrm{~kg} \mathrm{~N} \mathrm{ha}^{-1}$. From 2000 on, they were $\mathrm{N} 1=0, \mathrm{~N} 2=$ $60, \mathrm{~N} 3=120$, and $\mathrm{N} 4=180 \mathrm{~kg} \mathrm{~N}^{-1}$. Fertilizer rates were reduced for 2000 and thereafter because of the 1999 results on maize and the summarization of previous fertility research on switchgrass [30]. Rates on the switchgrass were N1, N2, and N3. Rates used on no-till maize were N2, N3, and N4. Ammonium nitrate fertilizer was broadcast with a bulk spreader throughout the duration of the study. The $0 \mathrm{~N}$ rate for switchgrass was used as a low input treatment only for switchgrass. In 2001, the switchgrass and corn subplots were split lengthwise into $9 \mathrm{~m}$ wide sub-subplots for harvest treatments.

\section{Switchgrass Management}

Switchgrass plots were seeded directly into the soybean stubble from the previous year using a no-till drill with a planting rate of $6.7 \mathrm{~kg} \mathrm{ha}^{-1}$ (pure live seed basis). A preemergence application of $2 \mathrm{~kg} \mathrm{ha}^{-1}$ atrazine [Aatrex $4 \mathrm{~L}^{\circledR}$; 6-chloro-N-ethyl-N'-(1-methylethyl)-1, 3, 5-triazine-2, 4diamine] was applied for weed control. There were no other management inputs the establishment year. The 60 and $120 \mathrm{~kg} \mathrm{~N} \mathrm{ha}^{-1}$ rates represent the low to high rates recommended switchgrass grown for bioenergy [30] with the 0 rate representative of a no-input system. A previous study [30] showed that switchgrass harvested after a killing frost had significantly less $\mathrm{N}$ in the biomass than switchgrass harvested at anthesis indicating $\mathrm{N}$ was being recycled to 
the roots of switchgrass late in the growing season. Beginning in 2001, harvest treatments were applied to the subsubplots within switchgrass cultivar N-fertility subplots to determine if harvest date might affect SOC. One harvest treatment $(\mathrm{H} 1)$ was a mid-August harvest and the other $(\mathrm{H} 2)$ was a harvest in October or November, following a killing frost. Plots were harvested only once a year. A $4.6 \times 0.9 \mathrm{~m}$ $\left(4.2 \mathrm{~m}^{2}\right)$ area was harvested in each subplot with a flail-type plot harvester in 1998 and the following April, all remaining biomass from the previous year was removed with a field harvester prior to spring green-up. In 1999 and thereafter, switchgrass yield harvests were made with flail harvesters and associated weighing equipment by harvesting a 0.9 to $1.8 \mathrm{~m}$ wide swath (varied with harvester used) the full $30 \mathrm{~m}$ length of the plots. At time of harvest, subsamples were collected from each sub-subplot, weighed for moisture content, dried at $50^{\circ} \mathrm{C}$ for $48 \mathrm{~h}$, and reweighed to determine dry matter content. Yields were adjusted to a dry weight basis. The $\mathrm{C}$ concentration of the switchgrass samples was determined using near infrared spectrometer (NIRS) procedures and calibrations [31]. A field flail harvester was used to remove all remaining biomass from the plots immediately following the yield harvests using the same harvest height of $10 \mathrm{~cm}$.

\section{Maize Management}

Maize seed was planted directly into soybean stubble of the previous year in 1999 with a no-till drill and the maize plots of the previous year thereafter. The maize was grown in $0.76 \mathrm{~m}$ wide rows. The $\mathrm{N}$ rates that were used represent the low-to-high rates for maize grown under rainfed conditions in the region. Nitrogen fertilizer was applied using the same equipment as for switchgrass plots. Glyphosate herbicide was applied after the maize had emerged and was about $40 \mathrm{~cm}$ in height. No other management inputs were applied until grain harvest. Aboveground samples (one row $4.4 \mathrm{~m}$ long) were collected soon after physiological maturity in each $\mathrm{N}$ rate subplot and later from each sub-subplot for total biomass yields. Ears were removed and stalks were then cut at ground level, chopped and weighed. A representative subsample was collected, dried and weighed for gravimetric moisture determination to calculate stover dry matter production. Ears were dried and weighed, added to the calculated stover weight to obtain total biomass yields on a dry weight basis. Maize grain yields were determined with a plot combine equipped with a weighing unit, subsamples were collected for moisture determination, and yields were adjusted to oven dry weight basis. Because of the emerging interest in using maize stover for biomass energy, in 2001 stover harvest treatments were applied to the sub-subplots. The harvest treatments were no residue harvested (H1) and approximately $50 \%$ of the stover remaining after grain harvest (H2). Stover was harvested from the $\mathrm{H} 2$ treatments after grain harvest using the flail forage harvesters that were used to harvest switchgrass plots. Harvested stover yields were determined by harvesting the stover from two nonborder rows of each sub-subplot its entire $30 \mathrm{~m}$ length with a plot-flail harvester. The remaining rows were harvested with a field scale flail harvester set at the same $10 \mathrm{~cm}$ height as the plot harvester. All stover weights were converted to a dry-weight basis $\left(50^{\circ} \mathrm{C}\right.$ oven for $\left.48 \mathrm{~h}\right)$. Maize grain and stover samples were analyzed for total $\mathrm{C}$ by dry combustion [32].

\section{Soil Sampling and Analysis}

Baseline soil samples were obtained in July 1998 and plots were thereafter re-sampled at approximately 3-year intervals in May 2001, April 2004, and in May 2007. The initial sampling location was in the center of each subplot. Subsequent soil samples were offset a fixed distance from each subplot or sub-subplot center to prevent re-sampling of a previous sampling site from which soil had been removed. Sample collection was done using the procedures described by Follett et al. [33]. In brief, the plant material was removed from the soil surface and then, using a flat-bladed shovel, undercutting and removing the soil from the $0-5,5$ 10 , and $10-30 \mathrm{~cm}$ depths. Samples were also collected from the 30-60, 60-90, 90-120, and 120-150 cm depths at the July 1998 and May 2007 sampling dates using a hydraulic probe. Soil bulk densities were determined using the USDANRCS National Soils Laboratory methods [34]. The standardized procedure (Soil Survey Laboratory method 3B1) to measure bulk density requires collection of field occurring fabric (clods), coating them with Saran F-310 in the field (NRCS 2004; Soil Survey Laboratory method 3B), transport to the laboratory, and desorption to $33 \mathrm{kPa}(1 / 3$ bar). After reaching equilibrium, the clod is weighed in air to measure mass and in water to measure its volume, and next dried at $110^{\circ} \mathrm{C}\left(230^{\circ} \mathrm{F}\right)$ with its mass and volume again determined. A correction is made for mass and volume of rock fragments and the plastic coating with the BD value reported for $<2 \mathrm{~mm}$ (0.079in) soil fabric.

Once samples were collected they were sieved through a $2 \mathrm{~mm}$ sieve and $<2 \mathrm{~mm}$ plant material picked from the soil, air dried (room temperature), subsampled, mechanically ground to pass through a $0.2-\mathrm{mm}$ sieve, and the subsamples were stored in sealed glass containers with screw type lids. All soils were checked for carbonates and in the very few cases where carbonates existed they were removed prior to analyses for organic $\mathrm{C}$ using accepted procedures $[35,36]$. All analyses were on an oven dry weight $\left(55^{\circ} \mathrm{C}\right)$. The methodology is such that both the isotopic $\mathrm{C}$ analyses and the analyses for the total SOC are done at the same time for the same sample. 
A subsample of soil from each layer was sieved $(2 \mathrm{~mm}$ sieve size) and picked free of remaining recognizable plant and root fragments under $\times 20$ magnification. Soil samples were oven dried $\left(55^{\circ} \mathrm{C}\right)$, finely ground, and then analyzed for total $\mathrm{SOC}$ and ${ }^{13} \mathrm{C} /{ }^{12} \mathrm{C}$ isotope ratio. All samples were analyzed for total $\mathrm{SOC}$ and ${ }^{13} \mathrm{C} /{ }^{12} \mathrm{C}$ isotope ratio using a continuous-flow Europa Scientific 20-20 Stable Isotope Analyzer (isotope ratio mass spectrometer) interfaced with Europa Scientific ANCA-NT system (automated nitrogen carbon analyzer) Solid/Liquid Preparation Module (Dumas combustion sample preparation system) (Europa Scientific, Crewe Cheshire, UK-Sercon Ltd.). Soil organic C was calculated using the $\mathrm{C}$ concentration (\%), soil bulk density $\left(\mathrm{g} \mathrm{cm}^{3}\right)$, and thickness for each individual sampled soil layer and then summed over layers. Soil organic $\mathrm{C}$ on an equivalent masses basis (SOC-EMB) also was calculated using the method of Ellert et al. [37]. The $120 \mathrm{~cm}$ soil depth data were used to make direct comparisons between both calculation methods in Table 1 and Supplementary Figs. S1 and $\mathrm{S} 2$. Procedures to calculate the $\mathrm{C} 3$ and $\mathrm{C} 4$ components of the SOC using $\delta^{13} \mathrm{C}(\%)$ are described by Deines [38] and Follett et al. $[33,39]$. For the purposes of this report, results from the $0-5,5-10$, and $10-30 \mathrm{~cm}$ depths were combined.

\section{$\delta^{13} \mathrm{C}$ Analysis}

Switchgrass and maize are both $\mathrm{C} 4$ plants that utilize the Hatch-Slack enzymatic pathway that is dominated by PEPcarboxylase which produces a $\mathrm{C}$ isotope fractionation between the $\mathrm{CO}_{2}$ in the air (currently about -8 mil $(\%=1 / 1,000$ th) [40], and about $-6.5 \%$ from the pre-industrial period back 10,000 years [41] and the plant of about $-4 \%$. The instrumental measurement of $\delta^{13} \mathrm{C}$ values are expressed relative to a calcium carbonate standard known as PDB from the Cretaceous Pee Dee formation in South Carolina [42]. Sign of $\delta^{13} \mathrm{C}$ indicates whether a sample has higher or lower $13 \mathrm{C} / 12 \mathrm{C}$ isotope ratio than $\mathrm{PDB}$. This pathway fractionates the isotopic composition of the plant so that a typical $\delta^{13} \mathrm{C}$ of $\mathrm{C} 4$ (warm season) plants relative to PDB is about -11 to $-13 \%$ o $[38,39]$. In contrast, the dominant photosynthetic pathway of $\mathrm{C} 3$ (or cool-season plants) is Calvin-Benson, whereby the enzyme
RuBP carboxylase produces a carbon isotope fractionation between the air and the plant of about $-18 \%$ so that the $\delta^{13} \mathrm{C}$ of $\mathrm{C} 3$ plants relative to $\mathrm{PDB}$ is about -26 to $-27[36,38]$. These differences make it feasible to determine the plant source $(\mathrm{C} 4$ or $\mathrm{C} 3)$ of SOC using mass-spectrometric analyses.

Equation 1 expresses ${ }^{13} \mathrm{C} /{ }^{12} \mathrm{C}$ ratio as $\delta^{13} \mathrm{C}$, which has "per mil" (\%) units. By convention, $\delta^{13} \mathrm{C}$ values are expressed relative to the PDB calcium carbonate standard [40]. The sign of $\delta^{13} \mathrm{C}$ indicates whether a sample has a higher or lower ${ }^{13} \mathrm{C} /{ }^{12} \mathrm{C}$ isotope ratio than does PDB.

$\delta^{13} \mathrm{C}(\%)=\underline{\left({ }^{13} \mathrm{C} /{ }^{12} \mathrm{C}\right) \text { sample }-\left({ }^{13} \mathrm{C} /{ }^{12} \mathrm{C}\right) \text { reference }} * 1000$

$$
\left({ }^{13} \mathrm{C} /{ }^{12} \mathrm{C}\right) \text { reference }
$$

Besides measurements of total $\mathrm{C}$ and $\delta^{13} \mathrm{C}$, fraction and weight of $\mathrm{C}$ originating from $\mathrm{C} 3$ plants and $\mathrm{C} 4$ plants were calculated based upon the mass of SOC and measured $\delta^{13} \mathrm{C}$ values (Eq. 1) of soil samples collected at the first and last soil sample collections, using Eqs. 2 and 3, and the $\delta^{13} \mathrm{C}$ of C3 and C4 plant material [39].

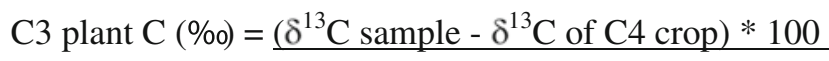

$$
\left(\delta^{13} \mathrm{C} \text { of } \mathrm{C} 3 \text { crop }-\delta^{13} \mathrm{C} \text { of } \mathrm{C} 4\right. \text { crop) }
$$

$\mathrm{C} 4$ plant $\mathrm{C}(\% \circ)=\underline{\left(\delta^{13} \mathrm{C} \text { of } \mathrm{C} 3 \mathrm{crop}-\delta^{13} \mathrm{C} \text { sample }\right) * 100}$

$$
\left(\delta^{13} \mathrm{C} \text { of } \mathrm{C} 3 \text { crop }-\delta^{13} \mathrm{C} \text { of } \mathrm{C} 4\right. \text { crop) }
$$

\section{Statistical Analyses}

The data were analyzed using Mixed Model analysis procedures of SAS [43] to determine the effects of $\mathrm{N}$ and harvest $(\mathrm{H})$ treatments on the grain and biomass yields and on changes in soil C. By using the Mixed Model analyses, it
Table 1 Mean, standard deviation, and range values for soil carbon (SOC) and soil organic carbon on an equivalent mass basis (SOC EMB) for switchgrass and maize plots at the initiation of the carbon sequestration study in 1998

\begin{tabular}{|c|c|c|c|c|c|c|}
\hline & \multicolumn{3}{|c|}{ SOC by depth in 1998} & \multicolumn{3}{|c|}{ SOC EMB in 1998} \\
\hline & $\begin{array}{l}0-30 \mathrm{~cm}^{-1} \\
\mathrm{Mg} \mathrm{Cha}^{-1}\end{array}$ & $0-120 \mathrm{~cm}$ & $0-150 \mathrm{~cm}$ & $\begin{array}{l}0-60 \mathrm{~cm} \\
\mathrm{Mg} \mathrm{Cha}^{-1}\end{array}$ & $0-90 \mathrm{~cm}$ & $0-120 \mathrm{~cm}$ \\
\hline Mean & 49.4 & 120.8 & 133.0 & 80.9 & 103.7 & 116.6 \\
\hline Standard deviation & 11.8 & 63.2 & 72.5 & 32.7 & 49.3 & 59.4 \\
\hline Range minimum & 30.2 & 57.8 & 60.1 & 40.2 & 51.2 & 56.4 \\
\hline Range maximum & 72.9 & 250.0 & 287.4 & 152.4 & 214.5 & 242.8 \\
\hline
\end{tabular}

The $0-120 \mathrm{~cm}$ depths can be used to make comparison between methods 
was possible to use a $t$ test to test if the change in soil $\mathrm{C}$ was significant for each $\mathrm{N} \times \mathrm{H}$ treatment for both switchgrass and maize.

\section{Results}

Biomass, Grain, and C Yields

We used different fertility levels and harvest treatments to create different management regimes and associated productivity levels so that their effects on SOC sequestration could be determined. As expected, switchgrass biomass yields increased with increasing $\mathrm{N}$ rates (Fig. 1). Switchgrass biomass yields were greater for harvests made after a killing frost than for harvests made at flowering in August. The $60 \mathrm{~kg} \mathrm{ha}^{-1} \mathrm{~N}$ rate on the maize plots had significantly lower total biomass, grain, stover, and grain $\mathrm{C}$ yields than the other two higher $\mathrm{N}$ levels which did not differ (Fig. 2). Harvesting and removing $50 \%$ of the maize stover resulted in small but significantly lower total biomass and grain yields (Fig. 2) which was expected based on an earlier report [44]. Harvested C yields (yield $\times \mathrm{C} \%$ ) were proportionally similar to biomass and grain yields because of limited variation in $\mathrm{C}$ concentration of the biomass and grain. These results show that management practices resulted in differences in harvested yields and C. We used two different upland switchgrass cultivars in the study to determine if there was a cultivar effect but cultivars did not differ in biomass yields over years (Supplementary Table 1) so results were summarized over cultivars. During the study

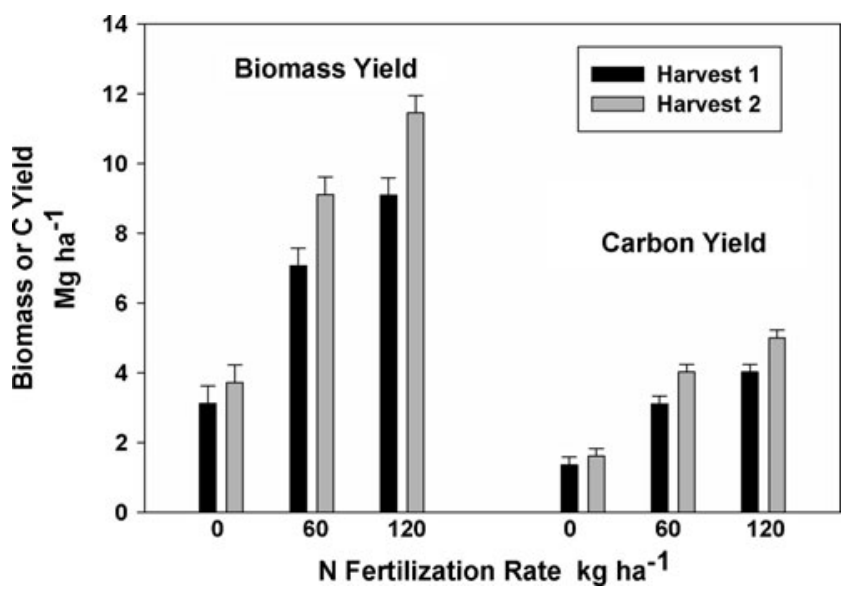

Fig. 1 Switchgrass mean annual biomass and C yields for years 1998 to 2007 in eastern Nebraska averaged over years and two upland cultivars. Treatments included three nitrogen fertilization rates and two harvest treatments. Harvest 1 was in August at anthesis. Harvest 2 was after a killing frost. There were no significant differences between cultivars. Harvest and fertilizer treatment effects were highly significant $(P \leq 0.01)$. Standard errors of means are shown as bars above the columns period, annual precipitation was variable but often was below normal (Fig. 3).

\section{Changes in Soil C}

Two main methods are used for reporting soil organic carbon. The most widely used method, which will be referred to as SOC, is based upon soil organic $\mathrm{C}$ concentration (\%), soil bulk density $\left(\mathrm{g} \mathrm{cm}^{3}\right)$, and thickness for each individual sampled soil layer and was the primary method used in this study. The other method is soil organic carbon expressed on an equivalent mass basis (SOC-EMB) [34]. The SOC and SOC-EMB results were very similar between depth increments and equivalent masses (approximated for the $0-30$, $0-120$, and $0-150 \mathrm{~cm}$ depth increments) because there were not large differences in bulk densities at any depth so the SOC-EMB results are reported only in the Supplementary Information (SI). Our results are reported as changes $(\Delta C)$ in SOC during the 9-year period. At the start of the study in 1998 , SOC in the $0-30 \mathrm{~cm}$ sampling depth varied by $40 \mathrm{Mg} \mathrm{ha}^{-1}$ among the plots in the field while in the 0 $150 \mathrm{~cm}$ sampling depth, SOC varied by almost $200 \mathrm{Mg} \mathrm{ha}^{-1}$ (Table 1). Soils in different areas of the field also varied widely for soil bulk density and other soil properties as is the situation in many marginally productive cropland fields.

In the switchgrass plots, there were significant, positive increases in SOC $(\Delta C)$ during the period $1998-2007$ for all soil depths and $\mathrm{N}$ rate $\mathrm{x}$ harvest treatment combinations except for $\Delta \mathrm{C}$ in the $0 \mathrm{~N}$ rate treatment plots for the 0 $30 \mathrm{~cm}$ sampling depth where the changes were positive but not significant (Fig. 4). The $\Delta \mathrm{C}$ values were statistically different from zero except for the $0 \mathrm{~N}$ rate for the $30 \mathrm{~cm}$ depth and increased across the depth ranges (0-30, 0-120, and $0-150 \mathrm{~cm}$ ). The magnitude and statistical significance level of the $\Delta \mathrm{C}$ changes varied with $\mathrm{N}$ rate and harvest management regimes. Harvest treatment effects on $\Delta \mathrm{C}$ were not significantly different averaged over $\mathrm{N}$ rates. Increases in SOC for the $0 \mathrm{~N}$ rate were less than for the fertilized treatments (Fig. 4). Cultivar effects were not significant for SOC $\Delta \mathrm{C}$ (Supplementary Table 2). Importantly, Fig. 4 shows that significant amounts of $\mathrm{C}$ were sequestered in the soil profile from 0 to $150 \mathrm{~cm}$ with over $50 \%$ of the total soil $\mathrm{C}$ sequestered deeper than $30 \mathrm{~cm}$ in the soil profile in switchgrass plots being managed for biomass production. The large standard errors for $\Delta \mathrm{C}$ are reflective of the initial soil variability in the field and likely will be found both within and among biomass production fields.

In the maize plots, SOC $(\Delta C)$ increased for all soil depths and $\mathrm{N}$ rate by harvest treatment combinations (Fig. 5) and were significantly different from zero (P levels ranged from 0.1 to 0.01 ) except for $120 \mathrm{~kg} \mathrm{~N} \mathrm{ha}^{-1}$ rate for the $120 \mathrm{~cm}$ sampling depth. Again, the magnitude and statistical significance level of the $\Delta \mathrm{C}$ changes varied with $\mathrm{N}$ rate and 


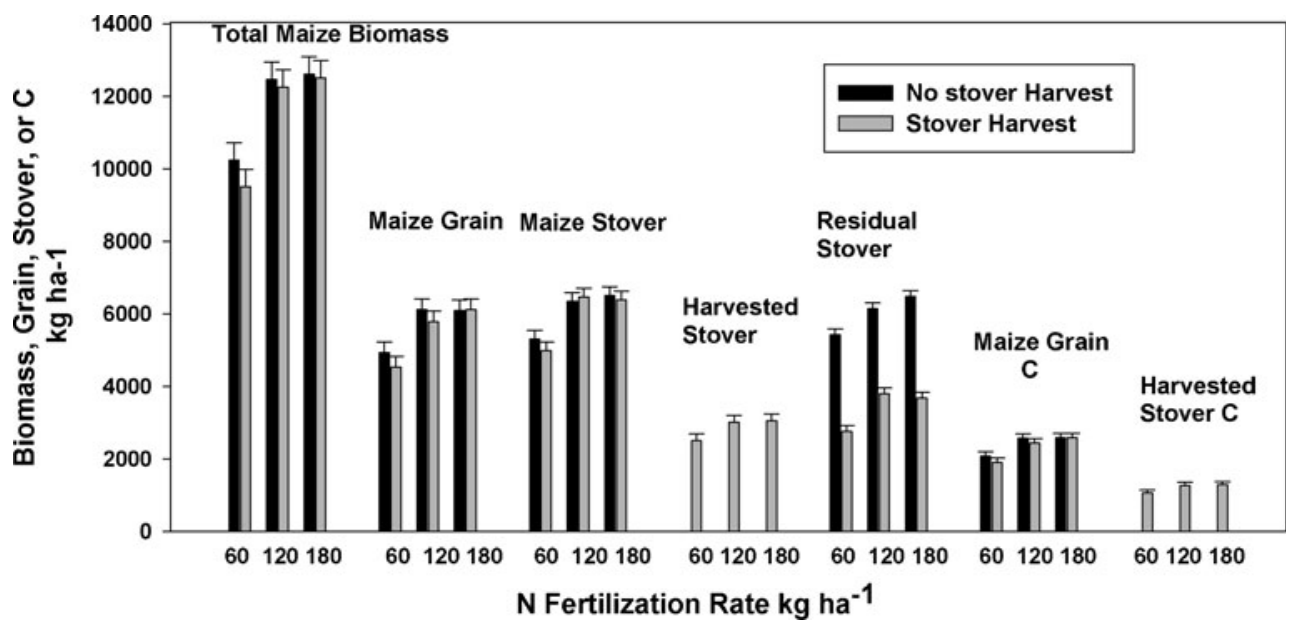

Fig. 2 Maize total biomass, grain, stover, harvested stover, residual stover, grain C, and harvested stover C mean yields for years 19992007 in eastern Nebraska in a non-irrigated, no-tillage production study. Harvested and residual stover yields and $\mathrm{C}$ yields are for years 2000-2007. Treatments included three $\mathrm{N}$ rates and two different stover harvest treatments $(\mathrm{H} 1=$ none; $\mathrm{H} 2=50 \%$ removal after grain harvest $)$. Standard errors of means are shown as bars above the columns.

harvest management regimes. Standard errors of the treatment means also were large because of the initial soil variability in the field. There were significant harvest treatment effects on $\Delta \mathrm{C}$ for the $0-30 \mathrm{~cm}$ sampling depth. Differences in $\Delta \mathrm{C}$ due to $\mathrm{N}$ fertility rates were not statistically significant across harvest treatments. These results show that significant increases in soil $\mathrm{C}$ occur in the soil profile from 0 to $150 \mathrm{~cm}$ in no-till maize in the western Corn Belt

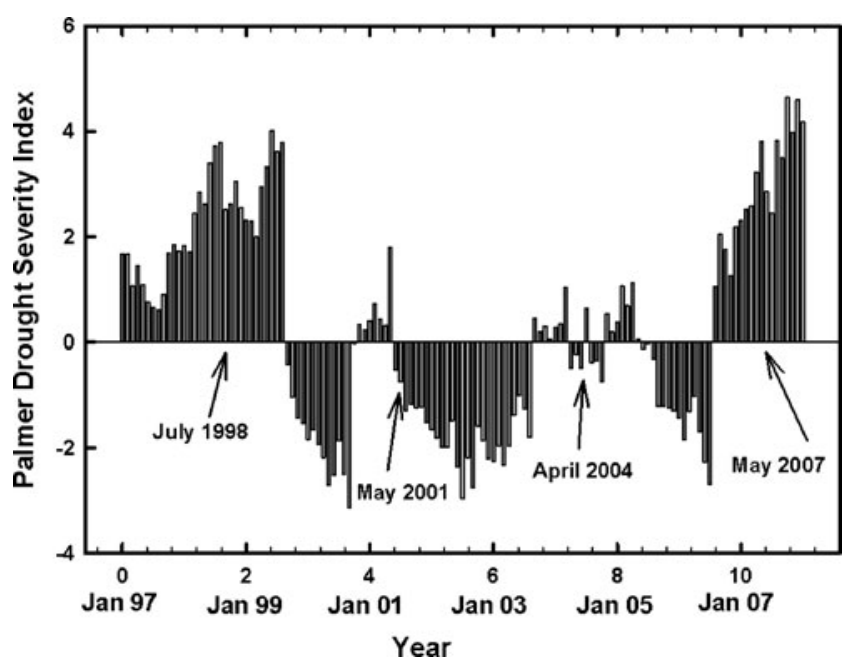

Fig. 3 Palmer Drought Severity Index (PDSI) for east central NE for the period 1997 to 2007. Negative PDSI values indicate degree of drought severity. The arrows indicate the four times that soil samples were taken in this study. Deep soil samples were taken only in 1998 and 2007. A period of moist weather during 1997 and 1998 preceded the drought periods that occurred during much of this study (http:// www7.ncdc.noaa.gov/CDO/CDODivisionalSelect.jsp\#, verified April, 3, 2012)
Harvest treatment effects were significant for total biomass $(P \leq 0.08)$, grain yield $(P \leq 0.05)$, and residual stover $(P \leq 0.01)$. The $60 \mathrm{~kg} \mathrm{ha}^{-1} \mathrm{~N}$ rate treatment differed significantly for all measured variables except for harvested stover and harvested $C(P \leq 0.05)$, from those of the 120 or $180 \mathrm{~kg} \mathrm{ha}^{-1}$ treatments which did not differ from each other. There were no significant $\mathrm{N}$ rate $\times$ harvest treatment interactions

region with both 0 and $50 \%$ stover harvest and show that over $50 \%$ of the total SOC is being sequestered deeper than $30 \mathrm{~cm}$ in the soil profile. A simple correlation analyses was conducted on the relationship between maize biomass yield,

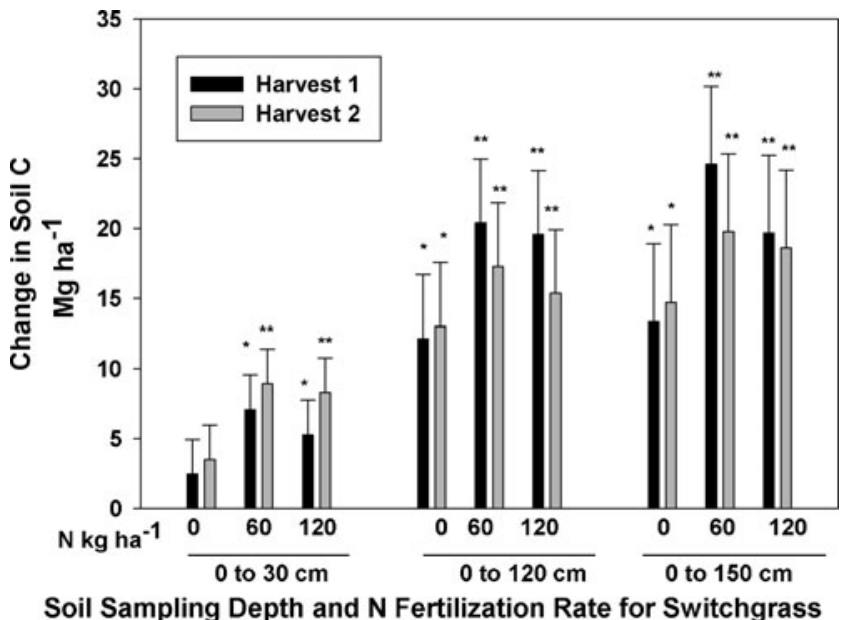

Fig. 4 Change in soil organic $C(\Delta C)$ from 1998 to 2007 at three soil depths in plots in eastern Nebraska in which two upland switchgrass cultivars were grown as biomass energy crop with three $\mathrm{N}$ fertilization rates and two harvest treatments as described in Fig. 1. Means were averaged over cultivars because cultivar effects were not significant for $\Delta \mathrm{C}$. The symbols, asterisk and double asterisks, above the standard error bars indicate if the change in soil $\mathrm{C}$ for each specific treatment and soil depth was significant at the 0.05 and 0.01 levels of probability, respectively. For $\Delta \mathrm{C}$, differences among harvest treatment effects were not statistically different significant but differences among $\mathrm{N}$ treatment effects were significant for the $0 \mathrm{vs} 60 \mathrm{~kg} \mathrm{~N} \mathrm{ha}^{-1}$ comparison $(P=0.10$ and 0.06 for the 30 and $150 \mathrm{~cm}$ sampling depths, respectively). The single harvests each year were made at either anthesis in August (Harvest 1) or after a killing frost (Harvest 2) in late October or early November 


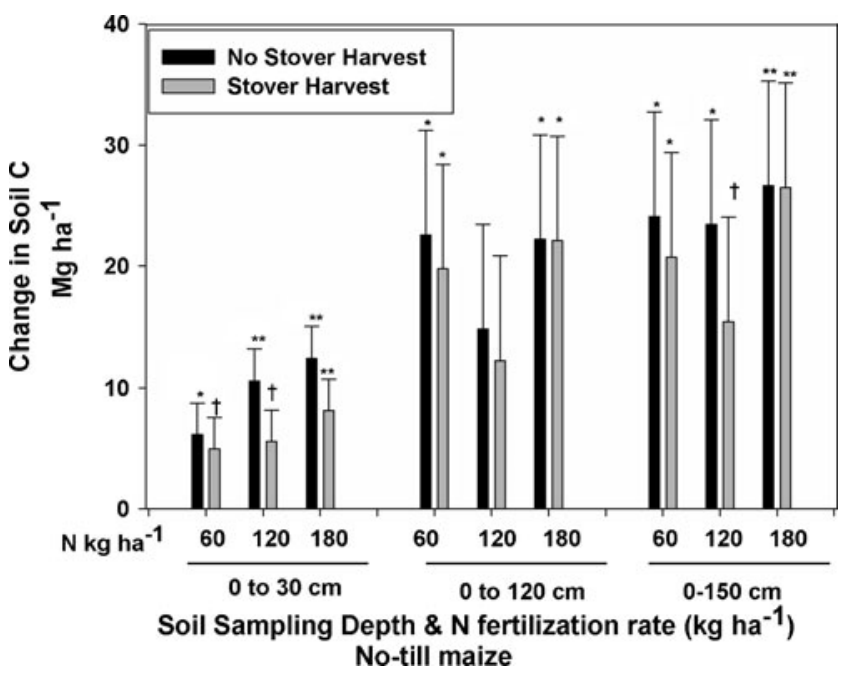

Fig. 5 Change in soil organic $\mathrm{C}(\Delta \mathrm{C})$ from 1998 to 2007 at three soil depths in plots in eastern Nebraska in which maize was grown without tillage with three $\mathrm{N}$ fertilization rates and two stover harvest treatments (0\% and $50 \%$ removal). The symbols, dagger, asterisk, and double asterisks, above the standard error bars indicate if the change in soil C $(\Delta C)$ for each specific treatments and soil depth was significant at the $0.1,0.05$, and 0.01 level of probability, respectively. Differences among harvest treatment effects for $\Delta \mathrm{C}$ were significant for the 0 to $30 \mathrm{~cm}$ soil $(P \leq 0.03)$ but not for the other sampling depths. Differences among $\mathrm{N}$ rate treatment effects were not significant for $\Delta \mathrm{C}$ averaged over harvests

grain yield, and residual stover versus $\Delta \mathrm{C}$ or $\Delta \mathrm{C}$-EMB. The only significant correlation was between residual stover and $\Delta \mathrm{C}(r=0.39, P=0.10)$.

\section{Sources of $\Delta \mathrm{C}$}

The $\delta^{13} \mathrm{C}$ isotope analyses of SOC showed essentially no change in the mass of C3 derived SOC from 1998 to 2007 (Figs. 6 and 7). The $\delta^{13} \mathrm{C}$ analyses of the SOC at each sampled depth increment in 1998 and 2007 showed that the major changes in SOC that occurred in these plots was in the C4 fraction which had to be derived from the switchgrass and maize that were grown continuously in the plots during that period (Figs. 6 and 7). The 2007-1998 differences in SOC were consistent for the switchgrass and maize plots and occurred throughout the soil profile from 0 to $150 \mathrm{~cm}$ in the plots. In the 1998 to 2007 period, the C4 SOC increased throughout the soil profile to depths of $150 \mathrm{~cm}$ for no-till maize and switchgrass.

\section{Discussion}

Our results clearly show that significant amounts of $\mathrm{C}$ were sequestered deep in the soil profile by switchgrass grown and managed as a biomass energy crop and maize grown continuously in a no-tillage production system under an

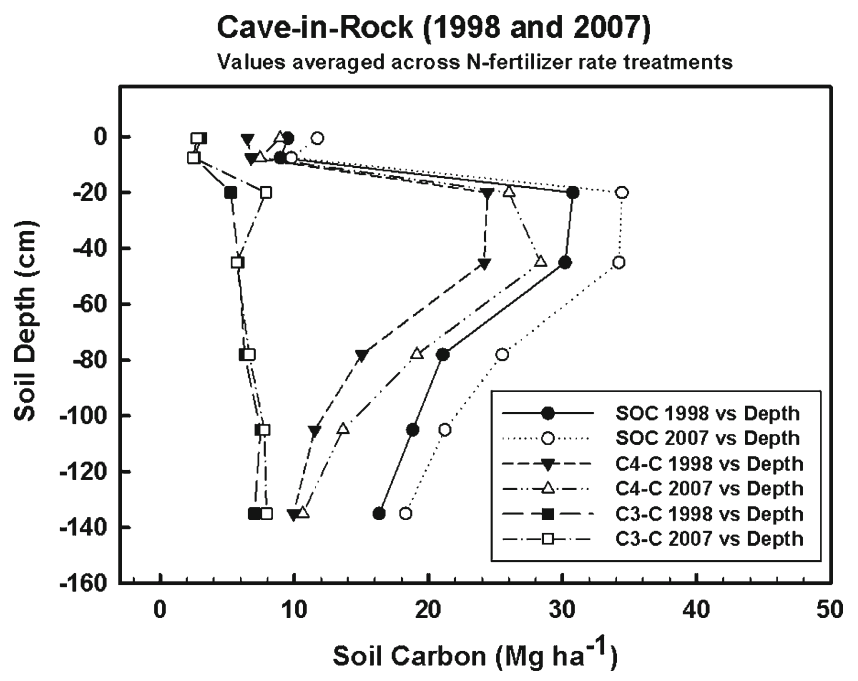

\begin{tabular}{|c|c|c|c|c|c|c|c|}
\hline \multicolumn{8}{|c|}{ Paired $t$-Test comparing $1998-$ to 2007 -data ${ }^{\S}$} \\
\hline Depth & Depth & \multirow{2}{*}{\multicolumn{2}{|c|}{$\begin{array}{l}\text { C3-C } \\
P \text { Value }\end{array}$}} & \multirow{2}{*}{\multicolumn{2}{|c|}{$\begin{array}{l}\text { C4-C } \\
P \text { Value }\end{array}$}} & \multirow{2}{*}{\multicolumn{2}{|c|}{$\begin{array}{l}\text { SOC } \\
P \text { Value }\end{array}$}} \\
\hline $\mathrm{cm}$ & ID & & & & & & \\
\hline $0-5$ & 1 & 0.270 & NS & 0.000 & $\star * \star *$ & 0.000 & *** \\
\hline 5-10 & 2 & 0.855 & NS & 0.000 & 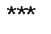 & 0.024 & ** \\
\hline $10-30$ & 3 & 0.000 & 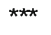 & 0.243 & NS & 0.002 & ** \\
\hline $30-60$ & 4 & 0.884 & NS & 0.004 & ** & 0.000 & *** \\
\hline 30-90 & 5 & 0.626 & NS & 0.000 & 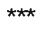 & 0.000 & *** \\
\hline-120 & 6 & 0.654 & NS & 0.001 & *夫* & 0.010 & ** \\
\hline $0-150$ & 7 & 0.252 & * & 0.337 & NS & 0.103 & NS \\
\hline
\end{tabular}

${ }^{\S} P$ Value: $+,{ }^{*},{ }^{* *},{ }^{* * *}=$ Significant at $0.1,0.05,0.01,0.001$

Degrees of Freedom $=17$

Fig. 6 Soil organic carbon (SOC) and soil carbon originating from plants with the $\mathrm{C} 3(\mathrm{C} 3-\mathrm{C})$ and $\mathrm{C} 4(\mathrm{C} 4-\mathrm{C})$ photosynthesis systems in the $0-150 \mathrm{~cm}$ soil profile of plots in which Cave-in-Rock switchgrass was grown as a bioenergy crop in eastern Nebraska. Soil samples were collected at the increments indicated at the beginning of the study in 1998 and in 2007. Depth increment values are averaged over $\mathrm{N}$ and harvest treatments. Paired $t$ tests were used to test for the significance of differences between the 1998 and 2007 soil samples. Results were similar for the cultivar Trailblazer

array of $\mathrm{N}$ fertility and harvest treatments for a 9-year period. For almost all other $\mathrm{C}$ sequestration reports used in bioenergy models, studies designed for other purposes were adapted to obtain soil $\mathrm{C}$ sequestration estimates, initial soil samples were not available, and control samples were from adjacent fields or non-treatment areas. Our results are supported by similar results reported by Liebig et al. [28] for four switchgrass fields managed with uniform $\mathrm{N}$ rates and harvest treatments for 5 years in the USA western Corn Belt. They are supported by the recent work of Varvel and Wilhelm [29] for maize in which significant increases in soil C occurred in soil layers up to $150 \mathrm{~cm}$ in depth in maize no-till plots as compared to tilled plots. The soil $\mathrm{C}$ that is sequestered deeper than $30 \mathrm{~cm}$ is expected to be more stable over time since it is below the tillage zone. Even in the top $30 \mathrm{~cm}$ of soil, sequestered $\mathrm{C}$ may be stable for extended periods in no-till production systems as reported previously by Follett et al. [33]. 
No-till Corn (1998 and 2007)

Values averaged across $\mathrm{N}$-fertilizer rate treatments

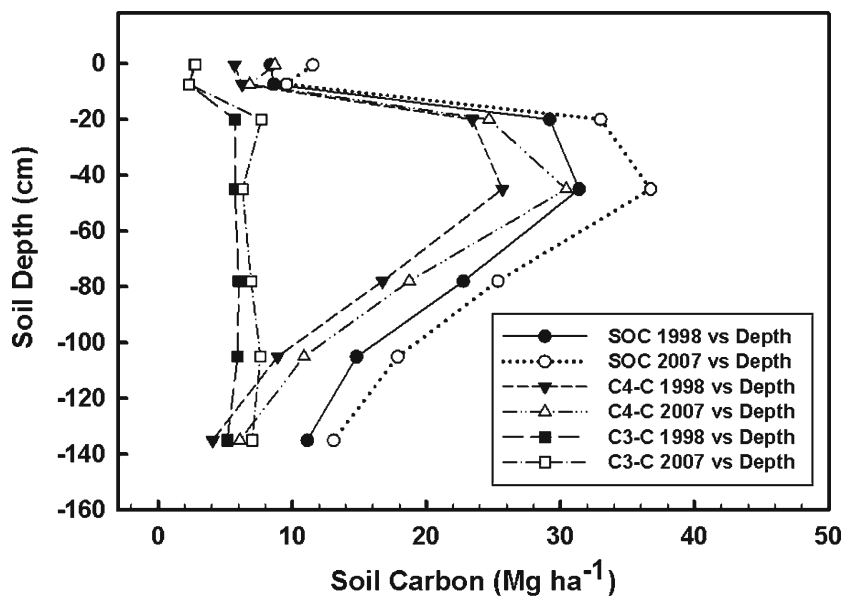

\begin{tabular}{|c|c|c|c|c|c|c|c|}
\hline \multicolumn{8}{|c|}{ Paired $t$-Test comparing 1998 - to 2007 -data $a^{\S}$} \\
\hline $\begin{array}{l}\text { Depth } \\
\mathrm{cm}\end{array}$ & $\begin{array}{l}\text { Depth } \\
\text { ID }\end{array}$ & \multicolumn{2}{|c|}{$\begin{array}{l}\text { C3-C } \\
P \text { Value }\end{array}$} & \multicolumn{2}{|c|}{$\begin{array}{l}\text { C4-C } \\
\text { PValue }\end{array}$} & \multicolumn{2}{|c|}{$\begin{array}{l}\text { SOC } \\
\text { PValue }\end{array}$} \\
\hline $0-5$ & 1 & 0.328 & NS & 0.000 & 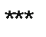 & 0.000 & *** \\
\hline $5-10$ & 2 & 0.000 & 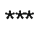 & 0.043 & ** & 0.001 & ** \\
\hline $10-30$ & 3 & 0.000 & *** & 0.083 & + & 0.000 & *** \\
\hline $30-60$ & 4 & 0.218 & NS & 0.005 & ** & 0.001 & *** \\
\hline $60-90$ & 5 & 0.273 & NS & 0.041 & * & 0.063 & + \\
\hline $90-120$ & 6 & 0.008 & $\star \star$ & 0.004 & $\star \star$ & 0.002 & ** \\
\hline $120-150$ & 7 & 0.001 & $\star \star \star$ & 0.003 & $\star \star$ & 0.002 & ** \\
\hline
\end{tabular}

${ }^{\S} P$ Value: $+,{ }^{*},{ }^{* *},{ }^{* *}=$ Significant at $0.1,0.05,0.01,0.001$

Degrees of Freedom $=17$

Fig. 7 Soil organic carbon (SOC) and soil carbon originating from plants with the $\mathrm{C} 3(\mathrm{C} 3-\mathrm{C})$ and $\mathrm{C} 4(\mathrm{C} 4-\mathrm{C})$ photosynthesis systems in the $0-150 \mathrm{~cm}$ soil profile of plots in which no-till maize was grown in eastern Nebraska. Soil samples were collected at the increments indicated at the beginning of the study in 1998 and in 2007. Depth increment values are averaged over $\mathrm{N}$ and harvest treatments. Paired $t$ tests were used to test for the significance of differences between the 1998 and 2007 soil samples

The switchgrass management practice with the greatest average biomass yields during the 1998 to 2007 period was the $120 \mathrm{~kg} \mathrm{ha}^{-1} \mathrm{~N}$ rate with harvest after a killing frost. The mean annual harvested biomass $\mathrm{C}$ yields for this treatment was $5.1 \mathrm{Mg} \mathrm{ha}^{-1}$ year $^{-1}$ (11.4 $\mathrm{Mg} \mathrm{ha}^{-1}$ year $^{-1}$ of total biomass). The average annual increase in SOC from 0 to $150 \mathrm{~cm}$ for this treatment was $2 \mathrm{Mg} \mathrm{ha}^{-1}$ year $^{-1}\left(7.3 \mathrm{Mg} \mathrm{CO}_{2}\right.$ $\mathrm{ha}^{-1}$ year $^{-1}$ ) which was equivalent to $40 \%$ of the harvested C. At the same fertilizer rate, maize grain yields were the greatest unless stover was removed. At the $120 \mathrm{~kg} \mathrm{ha}^{-1} \mathrm{~N}$ fertility rate with no stover harvest, the annual increase in soil $\mathrm{C}$ was $2.6 \mathrm{Mg} \mathrm{ha}^{-1}$ year $^{-1}\left(9.5 \mathrm{Mg} \mathrm{CO}_{2} \mathrm{ha}^{-1}\right.$ year $\left.^{-1}\right)$ which was equivalent to the harvested grain $\mathrm{C}$ yield. At the $120 \mathrm{~kg} \mathrm{ha}^{-1} \mathrm{~N}$ rate, stover harvest yielded $1.3 \mathrm{Mg} \mathrm{ha}^{-1}$ year $^{-1}$ of harvested $\mathrm{C}$ and resulted in a reduced, but not statistically different soil $\mathrm{C}$ sequestration rate as compared to the no stover harvest treatment. The difference in the switchgrass and maize annual $\mathrm{C}$ sequestration rate is probably due to switchgrass being a perennial with long root life whereas with maize, all roots die annually and likely also have different root biomasses and rhizdeposition. The low but positive correlation between residual stover and $\Delta \mathrm{C}$ support the previous work by Wilhelm et al. [21] who proposed that a critical sustainability factor in maize removal was the amount of crop residue left on the field.

Average annual $\mathrm{C}$ sequestration rates that occurred in both the switchgrass and maize plots under best management practices greatly exceed the soil $\mathrm{C}$ credits that have been used in LCA modeling studies to date for maize and switchgrass grown for bioenergy [7,9-12]. To illustrate the extent of the differences, we will use three of the most highly cited papers as examples. Hill et al. [11] assumed an average annual soil carbon sequestration rate for perennial grasses such as switchgrass of $0.566 \mathrm{Mg} \mathrm{ha}^{-1}$ year $^{-1}$ and zero $\mathrm{C}$ sequestration for maize. Searchinger et al. [12] used a $\mathrm{C}$ sequestration rate of $1 \mathrm{Mg} \mathrm{ha}^{-1}$ year $^{-1}$ of $\mathrm{CO}_{2}\left(0.273 \mathrm{Mg} \mathrm{ha}^{-1}\right.$ year $\left.^{-1} \mathrm{C}\right)$ for perennial grasses and again zero $\mathrm{C}$ sequestration for maize. Fargione et al. [9] also assumed zero $\mathrm{C}$ sequestration for maize and for perennial grasses used an unreported average of previously published values which were from 30 to $40 \mathrm{~cm}$ sampling depths. In some modeling studies, it is assumed that the rate of $\mathrm{C}$ sequestration with perennial grasses will decrease over time and that SOC sequestration will eventually cease in 30 to 50 years but data to support these assumptions is lacking for highly productive, managed grasslands and no-till maize. The time period over which the $\mathrm{C}$ sequestration rates obtained in this study with switchgrass and no-till can be sustained is unknown.

Our results indicate that the previous LCA of maize and switchgrass grown for bioenergy likely underestimated their net benefits because of the soil $\mathrm{C}$ sequestration data that were used in their analyses. For future LCA analyses of bioenergy crops, soil carbon sequestration data will need to be based on deep soil samples. For maize, perennial grasses, and other crops grown for bioenergy there will be regional differences in soils, environmental conditions, and best management practices all of which will likely produce regional differences in soil $\mathrm{C}$ sequestration or loss. Our results suggest that the use of uniform $\mathrm{C}$ sequestration rates across agro-ecoregions for LCA is a questionable practice. Also, the accrual rate over time in different production systems will need to be determined. We recognize that there is a large void in the information base on the net effects of agricultural and bioenergy production systems on changes in soil organic carbon below the tillage layer that needs to be addressed. The large standard errors obtained in this study for the effect of management practices on changes in SOC will likely exist within and across production regions. LCA includes multiple factors in addition to SOC and these factors also have associated standard errors. It seems obvious that in the future, LCA's should have standard errors associated with their outputs to reflect the variation that can occur in the variables on which they are based. 
Acknowledgments This research was funded by the U.S. Department of Agriculture (USDA), Agricultural Research Service (ARS) including funds from the USDA-ARS GRACEnet effort, and partly by the USDA Natural Resources Conservation Service. Authors acknowledge the important technical contributions of Edward Buenger, Elizabeth Pruessner, Susan Sampson-Liebig, Steven Masterson, Patrick Callahan, Kevin Grams, Stephan Swanson, and many student employees. The field assistance and coordination by Steve Scheinost, Asst. State Soil Scientist, USDA, NRCS, for Nebraska and laboratory support provided by the USDA, NRCS, Soil Survey Laboratory (National Soil Survey Center) is acknowledged.

USDA Information USDA is an equal opportunity provider and employer. Mention of trade names or commercial products in this publication is solely for the purpose of providing specific information and does not imply recommendation or endorsement by the U.S. Department of Agriculture.

Open Access This article is distributed under the terms of the Creative Commons Attribution License which permits any use, distribution, and reproduction in any medium, provided the original author(s) and the source are credited.

\section{References}

1. Robertson GP et al (2008) Sustainable biofuels redux. Science 322:49-50

2. Wang M (2001) Development and use of GREET 1.6 fuel-cycle model for transportation fuels and vehicle technologies (ANL/ ESD/TM-163) Argonne National Laboratory, U.S. Dept of Energy, Argonne, IL. www.transportation.anl.gov/pdfs/TA/153.pdf (verified April 3, 2012)

3. Andress D (2002) Soil carbon changes for bioenergy crops. Argonne National Laboratory, U.S. Dept of Energy, Argonne, IL. http://www.transportation.anl.gov/pdfs/AF/499.pdf (verified 3 April, 2012)

4. Parton WJ, Hartman MD, Ojima DS, Schimel DS (1998) DAYCENT and its land surface submodel: description and testing. Global Planet Change 19:35-48

5. Liang Y et al (2009) Simulating soil organic matter with CQESTR (v 2.0): model description and validation against long-term experiments across North America. Ecol Model 220:568-581

6. Adler PR, Del Grosso SJ, Parton WJ (2007) Life-cycle assessment of net greenhouse-gas flux for bioenergy cropping systems. Ecol Appl 17:675-691

7. Anderson-Teixeira KJ, Davis SC, Masters MD, Delucia EH (2009) Changes in soil organic carbon under biofuel crops. GCB Bioenergy 1:75-96

8. Burney JA, Davis SJ, Lobell DB (2010) Greenhouse gas mitigation by agricultural intensification. Proc Natl Acad Sci USA 107:12052-12057

9. Fargione J, Hill J, Tilman D, Polasky S, Hawthorne P (2008) Land clearing and biofuel carbon debt. Science 319:1235-1238

10. Gollany HT, Rickman RW, Liang Y, Albrecht SL, Machado S, Kang S (2011) Predicting agricultural management influence on long-term soil organic carbon dynamics: implications for biofuel production. Agron J 103:234-246

11. Hill J, Nelson E, Tilman D, Polasky S, Tiffany D (2006) Environmental, economic, and energetic costs and benefits of biodiesel and ethanol biofuels. Proc Natl Acad Sci USA 103:11206-11210

12. Searchinger T et al (2008) Use of U.S. croplands for biofuels increases greenhouse gases through emissions from land-use change. Science 319:1238-1240
13. Follett RF, Kimble JM, Pruessner G, Samson-Liebig SE, Waltman SW (2009) Soil organic carbon stocks with depth and land use at various U.S. sites. In: Lal R, Follett R (eds) Soil carbon sequestration and the greenhouse effect, Spec. Pub. 57. Soil Science Society of America, Madison, pp 27-40

14. Frank AB, Berdahl JD, Hanson JD, Liebig MA, Johnson HA (2004) Biomass and carbon partitioning in switchgrass. Crop Sci 44:1391-1396

15. Garten CT, Wullscheleger SD (2000) Soil carbon dynamics beneath switchgrass as indicated by stable isotype analyses. J Environ Qual 29:645-653

16. Lee DK, Owens VN, Doolittle JJ (2007) Switchgrass and soil carbon sequestration response to ammonium nitrate, manure, and harvest frequency on conservation reserve program land. Agron J 99:462-468

17. Liebig MA, Johnson HA, Hanson JD, Frank AB (2005) Soil carbon under switchgrass stands and cultivated cropland. Biomass Bioenergy 28:347-35

18. U.S. Department of Energy (2011) U.S. billion-ton updated: biomass supply for a bioenergy and bioproducts industry. In: Perlack RD, Stokes BJ (Leads), ORNL/TM-2011/224. Oak Ridge National Laboratory, Oak Ridge, TN, p 227

19. Graham RL, Nelson R, Sheehan J, Perlack RD, Wright LL (2007) Current and potential US corn stover supplies. Agron J 99:1-11

20. Huggins DR, Reganold JP (2008) No-till: the quiet revolution. Scientific American July, pp 70-77

21. Wilhelm WW, Johnson JM, Karlen DL, Lightle DT (2007) Corn stover to sustain soil organic carbon further constrains biomass supply. Agron J 99:1665-1667

22. Al-Kaisi MM, Yin X, Licht MA (2005) Soil carbon and nitrogen changes as influence by tillage and cropping systems in some Iowa soils. Agr Ecosyst Environ 105:635-647

23. Baker JM, Ochsner TD, Venterea RT, Griffis TJ (2007) Tillage and soil carbon sequestration — what do we really know? Agr Ecosyst Environ 118:1-5

24. Balesdent J, Wagner GH, Mariotti A (1988) Soil organic matter turnover in long-term experiments as revealed by carbon-13 natural abundance. Soil Sci Soc Am J 52:118-124

25. Blanco-Canqui H, Lal R (2008) No-tillage and soil-profile carbon sequestration: an on-farm assessment. Soil Sci Soc Am J 72:693701

26. Blanco-Canqui H, Lal R (2009) Corn stover removal for expanded uses reduces soil fertility and structural stability. Soil Sci Soc Am J 73:418-426

27. West TO, Marland G (2002) A synthesis of carbon sequestration, carbon emissions, and net carbon flux in agriculture; comparing tillage practices in the United States. Agr Ecosyst Environ 91:217-232

28. Liebig MA, Schmer MR, Vogel KP, Mitchell R (2008) Soil carbon storage by switchgrass grown for bioenergy. BioEnergy Res $1: 215-222$

29. Varvel GE, Wilhelm WW (2011) No-tillage increases soil profile carbon and nitrogen under long-term rainfed cropping systems. Soil Tillage Res 114:28-36

30. Vogel KP, Brejda JJ, Walters DT, Buxton DR (2002) Switchgrass biomass production in the Midwest USA: harvest and nitrogen management. Agron J 94:413-420

31. Vogel KP, Dien BS, Jung HJ, Casler MD, Masterson S, Mitchell RB (2011) Quantifying actual and theoretical biomass ethanol yields for switchgrass strains using NIRS analyses. Bioenergy Res 4:96-110

32. Schepers JS, Francis DD, Thompson MT (1989) Simultaneous determination of total $\mathrm{C}$, total $\mathrm{N}$, and $15 \mathrm{~N}$ on soil and plant material. Comm Soil Sci Plant Anal 20:949-959

33. Follett RF, Varvel GE, Kimble JM, Vogel KP (2009) No-till corn after bromegrass: effect on soil $\mathrm{C}$ and soil aggregates. Agron J 101:1-8 
34. USDA-NRCS (Natural Resources Conservation Service) (2004) Soil survey laboratory methods manual. Soil Survey Investigations Report No. 42. Version 4.0. In: Burt R (ed). Available at http:// soils.usda.gov/technical/lmm/ (verified April 3, 2012)

35. Follett RF, Paul EA, Leavitt SW, Halvorson AD, Lyon D, Peterson GA (1997) Carbon isotope ratios of Great Plains soils in wheatfallow systems. Soil Sci Soc Am J 61:1068-1077

36. Follett RF, Pruessner EG (2001) Intralaboratory carbon isotope measurements on five soils. In: Lal R, Kimble JM, Follett RF, Stewart BA (eds) Assessment methods for soil carbon. Lewis Publishers, Boca Raton, pp 185-192

37. Ellert BH, Janzen HH, McConkey BG (2001) Measuring and comparing soil carbon. In: Lal R, Kimble JM, Follett RF, Stewart BA (eds) Assessment methods for soil carbon. Lewis Publishers, Boca Raton, pp 131-146

38. Deines P (1980) The terrestrial environment. In: Fritz P, Fontes JC (eds) Handbook of environmental isotope geochemistry, volume 1, vol 1. Elsevier, Amsterdam, pp 329-406
39. Follett RF, Kimble JM, Leavitt SW, Pruessner E (2004) Potential use of $\mathrm{C}$ isotope analyses to evaluate paleoclimate. Soil Sci 169:471-488

40. Keeling $\mathrm{CD}$ et al. (2001) Exchanges of atmospheric $\mathrm{CO}_{2}$ and ${ }^{13} \mathrm{CO}_{2}$ with the terrestrial biosphere and oceans from 1978 to 2000. I. Global aspects. Scripps Institute of Oceanography SIO Reference No. 01-06, Revised from SIO Reference No. $00-21$

41. Leuenberge M, Siegenthaler U, Langway C (1992) Carbon isotope composition of atmospheric $\mathrm{CO}_{2}$ during the last ice age from an Antarctic ice core. Nature 488:488-490

42. Boutton TW (1991) In: Coleman DC, Fry B (eds) Carbon isotope techniques. Academic, New York, pp 155-171

43. SAS (2002) SAS 9.1 for Windows,SAS Institute Inc. Cary, NC, USA

44. Varvel GE, Vogel KP, Mitchell RB, Follett RF, Kimble JM (2008) Comparison of corn and switchgrass on marginal soils for bioenergy. Biomass Bioenergy 32:18-21 